Athens Journal of Business \& Economics -

Volume 7, Issue 3, July 2021 -Pages 227-244

\title{
Farmers Willingness to Pay for Participatory Poultry Research in Kwara State, Nigeria: Ex-ante Approach
}

\author{
By Rapheal Olanrewaju Babatunde*, Adedayo Olufemi Adekunle ${ }^{ \pm}$, \\ Gbenga Opeyemi $i^{+} \&$ O. Agboola ${ }^{+}$
}

\begin{abstract}
This study examined farmers' willingness to pay for participatory poultry research in Kwara State, Nigeria using ex-ante approach. The study utilized primary data collected with the aid of structured questionnaire. A random sampling technique was utilized to select a total number of 102 poultry farmers from Poultry Association of Nigeria (PAN) Kwara State Chapter. Descriptive statistics, Contingent Valuation $(\mathrm{CV})$ techniques and probit regression model were used to achieve the research objectives. The CV results showed that $64.7 \%$ of the households were willing to pay. The monthly individual aggregate WTP amount ranged from $\$ 2,000$ to $\$ 6,000$, and on average $\$ 2,576$ per month, generating aggregate annual values ranging from $\$ 12,000.00$ to $\$ 72,000.00$ and on average $\$ 30,912.00$ (ceteris paribus). Probit regression model demonstrated a significant ( $p<0.01, p<0.05$ or $p<0.10)$ relationship between household size, educational attainment and age of the household head and WTP. The study concluded that majority of the farmers were willing to pay for participatory research. Policy makers and other relevant stakeholders should take advantage of the significant socio-economic factors influencing the decision to participate in poultry research initiatives when formulating policies. This will help improve poultry production in the country.
\end{abstract}

Keywords: participatory poultry research, willingness-to-pay (WTP), probit regression

\section{Introduction}

The agricultural sector in Nigeria is the most important non-oil economic activity and it is the single largest employer of labour forces, employing about 70 percent of its workforce (NBS 2009). It contributed $40.07 \%$ and $22 \%$ (pre and post debasing period respectively) of Gross Domestic Products (GDP) in 2010 and 2014 respectively (NBS 2014). The sector consists of crops, fishery, forestry and livestock sub-sectors. The GDP contributed by sub-sectors are; crops $(36.40 \%)$, fisheries $(1.34 \%)$ forestry $(0.52 \%)$ and livestock $(2.61 \%)$. The livestock sub-sector

\footnotetext{
*Associate Professor, Department of Agricultural Economics and Farm Management, University of Ilorin, Nigeria.

${ }^{ \pm}$Graduate Student, Department of Agricultural Economics and Farm Management, University of Ilorin, Nigeria.

${ }^{\ddagger}$ Graduate Assistant, Department of Agricultural Economics and Extension, Kogi State University, Nigeria.

${ }^{+}$Graduate Student, Department of Agricultural Economics and Farm Management, University of Ilorin, Nigeria.
} 
is an important component of the Nigeria agricultural economy. The Nigeria's livestock population consists of 16.3 million Cattle; 40.8 million Goat; 27 million Sheep; 3.7 million Pigs and 151 million poultry (Adeyonu et al. 2014).The poultry industry plays important roles in the development of Nigeria economy. The industry provides employment opportunities for the populace, thereby serving as a source of income to the people. Also, it provides a good source of animal protein in terms of meat (chicken) and eggs (Apantaku 2006).

World agriculture in the 21 st century will face three major challenges namely, how to feed a growing world population, how to contribute to reducing the stillhigh prevalence of rural poverty in the world, and how to respond to increased concerns about managing the natural resource base (McCalla 2001). There has never been a time which agricultural production between developed and developing economies is balance. According to Hayami and Godo (2004) the disequilibrium of world agriculture has been worsening as manifested by increasing food deficit in developing economies in contrast with increasing surplus in developed economies. For economic development to succeed in Africa in the next 50 years, African agriculture will have to change significantly. Production would have to have to increase massively along with increasing productivity (Collier and Dercon 2009). Dramatically increasing the global food supply is a daunting enough challenge on its own, but several significant headwinds make the task even more complicated, underscoring the need for innovative solutions. Human ingenuity and innovation have always been at the core of meeting challenges, and in doing more with less (Global Food Security Index 2015).

Furthermore, report shows that the link between agricultural innovation and food security is positive. Technologies enhance agricultural productivity gains and lower per unit costs of production, with the effects of raising the incomes of producers and of shifting outward the supply curve (Kassie et al. 2012). The decisive measure for this kind of innovation-led growth is the "total factor productivity", i.e., the ratio of total commodity output (the sum of all crop and livestock products) to total inputs used in production, including all land, labor, capital, and materials. If total output is growing faster than total inputs, this is an improvement in total factor productivity. Increase in total factor productivity implies that more output is being produced from a given bundle of agricultural resources (Fuglie and Nin-Pratt 2013).

The important element of any innovation transfer is the appropriate adoption of such technology without any hitch (Oyeniyi et al. 2008). Why have peasant farmers in Africa not adopted modern agricultural technology more readily? In the past the most common diagnosis was peasant ignorance or cultural conservatism. The answer then 'obviously' laid in programmes of education and extension hence the major investments in improving extension services in the 1950s and 1960s. The oft-repeated exhortation to 'educate the farmers' can still be heard today in some quarters (Scoones and Cousins 1989).

Poultry research is an important process to improve poultry production.

Extension agents are mostly government agents saddled with the responsibility of providing services to farmers. Public extension services reach a large number of farmers in Nigeria. According to Global Forum for Rural Advisory Services 
(GFRAS) (1997), Extension services enable farmers to take up innovations, improve production, and protect the environment. Extension shows positive effects on knowledge, adoption, and productivity; agricultural extension service as comprising all the different activities that provide the information and advisory services that are required, and demanded, by farmers and other actors in the agrifood systems and rural development. Agricultural extension strengthens a farmer's capacity to innovate by providing access to knowledge and information (Emmanuel et al. 2016).

Extension and research are well-organized systems that design and disseminate technological innovations to farmers. Despite all the technological innovation transfer, the wide gap between levels of production which research contends is attainable and that which farmers achieve suggests a missing link (Oladele 2002). The capacity gap is particularly large in tropical regions, where poverty is pervasive (FAO 2014). Hence, innovation is not a one way street from research to users but can actually also be created by the users themselves. In fact, innovation primarily takes place within value chains and should subsequently be integrated into a responsive and demand-oriented agricultural education and research system (Spielman and Birner 2008). Thus, agricultural innovations are needed to sustainably increase productivity, i.e., output per unit of all inputs, while maintaining environmental quality and resources. Such innovations require enhanced investments in research and development. Innovation in the agricultural sector is a key to ensure food security and achieve the right to food. Innovations are needed to accelerate the rate of increase of per capita production sustainably over the next years and decades to keep up with increasing and changing demand from a growing population (Husmann et al. 2015).

Therefore, proper harnessing of local resources of the poor people and their involvement in the research process can help bring about development of sustainable livelihoods and contribute to the fight on poverty alleviation in rural areas where the majority of the poor live (Ndegwa 2013, Gonsalves et al. 2005). Marilee (2000) has noted that participation can take many different forms at different stages of a project cycle ranging from contribution of inputs in predetermined projects and programmes, to information sharing, consultation, decision-making, partnership and empowerment. Participation as a means is a process in which people and communities cooperate and collaborate in development projects and programmes while as an end, it is a process that empowers people and communities through acquiring skills, knowledge and experience, leading to greater self-reliance and self-management. Farmerparticipatory research (FPR) can help improve the effectiveness of technology development, raise adoption rates, and increase the payoff to agricultural research (Freeman, 2001).

In recent years many studies have shown the major objectives and benefits of farmers' participatory research approach; they have some notable benefits such as improvement of farmers' capacity building, utilization of local resources etc. (Ndegwa 2013, Gueye 2000, Marilee 2000). Hence, those studies did not address specific sector, they were generalized on agriculture and there are more studies on farmers' participatory research and willingness to pay for research addressed crop 
production than livestock production. Few of these studies were directed at willingness to pay for research and extension (Ibrahimet al. 2013, Birner et al. 2006). Other studies only treated willingness to pay for services or willingness to pay for inputs such as vaccines and vaccination services (Mbabazi 2015). There is however, no published peer-reviewed materials regarding the willingness of the poultry farmers to pay for participatory research in Nigeria as at the time of carrying out the study and it is unclear whether the farmers are aware of this approach, if they are aware, are they willing to pay the price involved? The answer to this question still remained in unclear. This study therefore explores and explains poultry farmers' willingness to pay for participatory poultry research in Nigeria. There is a need to address this among the livestock farmers and in particular in poultry sector because of its importance to the economy of the country as well as the benefits of farmers' participatory research.

The study utilized Ex-ante approach in the study. The term ex-ante (sometimes written ex ante or exante) is a phrase meaning "before the event". Ex-ante is used most commonly in the commercial world, where results of a particular action, or series of actions, are forecast in advance (or intended). Ex-ante evaluation studies have largely two purposes: i) project planning and ii) the evaluation planning. This paper will contributes to the growing body of knowledge on the value of the willingness of poultry farmers to pay for participatory poultry research in Nigeria. The result of this study is useful for policy formulation by government at all levels. It will serve also as a reference material to researchers and students alike. The main objective of this paper is to examine the willingness of poultry farmers to pay for participatory poultry research in Nigeria: using ex ante approach. The specific objectives are to;

i. determine farmers' awareness and perception of participatory poultry research in the study area;

ii. determine the farmers' willingness to pay for participatory research;

iii. examine the average price that farmers are willing to pay for poultry research; and,

iv. identify the determining factors affecting the farmers' willingness to pay for participatory poultry research in the study area.

\section{Literature Review}

Much literature is available on the subject of farmers participation in agricultural research, advocating it as the most effective rural development approach but the studies that examine the ex-ante analysis of farmers' willingness to pay for participatory poultry research are scarce particularly in Nigeria. The study is common with crop production than in animal husbandry. In this regard, Chambers et al. (1989) and Bentley (2000) have presented excellent review of literature on farmers' participatory research (FPR). From the available studies, we can conclude that both farmers and researchers benefit from farmers participatory research approach. It leads to innovation development, empowerment of farmers, 
learning, adapt and do better; it reduces the research and extension costs; it makes the research to utilize the local resources available to farmers and those the farmers familiar with; it has helped develop technologies that are more appropriate to small farmers; and it has helped improve the trust between farmers and researchers. It can also be deduced that researchers take the advantage of working with many farmers in different environment to discover more problems being faced by the farmers. It makes the researchers and the extension agents to discover the farmers' knowledge about their farms, quoting the words of one trainee from FARMAfrica,

"Before training I considered myself as if I knew more than the farmer about his situation. I was conducting surveys and research on the farms without consulting the farmer. I undermined his ideas, views and experiences. But after the training, my understanding has completely changed. Now I believe that the farmers do know their problems better than anyone else".

In the remaining part of this section, we present a brief review of empirical studies on farmers' participatory research and willingness to pay for the research by the farmers.

FARM-Africa (2001), in the farmers' research project located in south western Ethiopia, which is firmly based on the principles of farmer participatory research (FPR), aimed at creating better linkages and understanding between farmers, researchers and extension staffs; developing a better understanding of ways in which farmer participatory research can be conducted in Ethiopia; enhancing the capacity of GOs and NGOs to enable farmers to undertake farmer participatory research; stimulating and encourage the incorporation by GOs and NGOs of farmer participatory research into their own organisational activities. The study showed that, Farmers' Research Project has had considerable success in raising the awareness and improving the technical capacity related to farmer participatory research, in collaborating governmental organisations, i.e., the Bureau of Agriculture, the Awassa Research Centre and the Awassa College of Agriculture. It has brought about a huge, positive change in attitudes to local farmers and their farming systems among research and extension staff, coupled with the spread of practical experience in the use of farmer participatory research methodologies. Through the range of activities promoted by FRP research and extension staffs have also become much better informed about local agricultural systems, their rationale and their constraints. Ndegwa et al. (2015) in a study carried out to evaluate uptake by farmers of improved management practices (interventions) and their effect on performance of indigenous chickens at farm level and consequences for farmer participation in the implementation of research activities. Four villages were selected per region and 10 farms in each village. Interventions housing, feed supplementation, vaccination and deworming were implemented by farmers and monitoring and evaluation were carried out. Farmers used own local inputs in implementing the project interventions and recorded various project activities and outputs. The project was monitored over a span of five, 3-month long periods. The study discovered that, feed supplementation had high level of use by all farmers in 
each period. More farmers applied deworming in later periods, $25 \%$ had vaccination in period $1,40 \%$ in period 5, and flock sizes rose from 10-20 birds per farm to 20-30. It was concluded that, Farmer participatory research is a tool for technology testing and transfer and a quick and effective means of generating and disseminating information.

In another study by Ndegwa et al. (2013) in an on-farm farmers' participatory research project was carried out in Kenya to improve the management of indigenous chicken and their productivity at farm level, in five different agroecological zones. The project aimed to improve management and productivity of indigenous chicken at farm level, to change attitudes towards indigenous chicken, to improve farmers capacity and ability to carry out research (involve them in design, implementation and monitoring activities) using local resources and, to exploit the potential of indigenous chickens to contribute to poverty alleviation among rural landless people mainly women. In each region, four clusters (each cluster from a different village) were selected comprising of ten farmers each. This was followed by farmer training workshops that were held at cluster level. Implementation of a variety of improved management practices was done largely by use of local resources and farmers participation. Monitoring and evaluation were done continuously by farmers and on a regular basis by the research team. The project succeeded in the way of creation and enhancement of social capital by bringing together individual farmers and the research team to interact freely and share information, knowledge and experiences. Mutual trust, interest and enthusiasm were generated. Farmers were able to implement a variety of interventions from a basket of options, at their own pace and, with their own locally available resources. It was concluded that involvement of beneficiaries in anti-poverty initiatives is an imperative if the objectives are to be achieved. Aklilu (2007) in a study aimed to integrate participatory-, survey- and model-based approaches to socio-technical analysis and mutual farmer-researcher learning about constraints to and opportunities for village poultry development in Ethiopia. It used a data collection methods individual and open-group interviews, a crosssectional stratified random survey, farm-recording, a market survey, and villagepoultry Modeling. Feed-back workshops were organised to share between farmers and researchers the data collected through farm-recording and to learn about outcomes of simulation scenarios for identifying improvement options of village poultry systems. The result indicated that through the combination of multiple approaches and methods researchers can arrive at better understanding of constraints affecting farmers' reality. The study also confirmed that village poultry research and development are not only about finding technical solutions but also involve addressing household livelihoods, and institutional and policy issues from a social science perspective.

On the other hand, studies on farmers' willingness to pay for farmers' participatory research are not available in Nigeria. In a study to determine the willingness and capacity of poultry farmers to pay for extension services in Nasarawa State, Nigeria by Ibrahim et al. (2013), the study used Kuppuswamy scale and logit regression model. The result revealed that poultry farmers in the study area are willing and also have the capacity to pay for extension services 
especially on disease control and vaccination of poultry birds. This implies that the hitherto inefficient public livestock extension services can be strengthened if livestock farmers are charged reasonably for extension services rendered to them.

However, some researchers have divergent opinions; some shortcomings in the concept of participation have been raised by various authors. Much literature is available on the subject of participation, advocating it as the most effective rural development approach as said earlier. But some shortcomings in the concept of participation have been raised by various authors. However, many projects promote participation but areinitially unaware of the full implications of the participatory process. The concept has been applied in many fields, including rural development, health provision, industry management, and agriculture, among others (Oakley 1991). There are several barriers between farmers and scientists, not the least of which is social distance. Farmer participatory research (the collaboration of farmers and scientists in agricultural research and development) is a promising idea that has not lived up to its promise (Bentley 2000).

According to Bently (2000), FPRbuilt on a foundation of many successful experiences it has had problems. A review of 25 case studies of FPR show that sustaining farmer participation beyond initial, diagnostic stages was more difficult than researchers had anticipated. In most cases, the participation of farmers in FPR was relatively passive. There were very few examples of farmers and scientists working as colleagues. Hall and Nahdy (1999), in their study of farmer participatory research in the National Agricultural Research Systems NARS in the case of Uganda pointed out some problems of FPR. They emphasized thatFPR has largely failed in its attempts to improve the efficiency of agricultural research by restructuring science/production relations. This failure is the result of the 'systems problem' in agricultural research, whereby the complex interrelationship of actors, institutions and resources prevents FPR methods being compatible with the NARS. The study stressed further the nature of these problems, five problem areas were identified which appear to be representative of the wider context of the research system: researcher/farmer power relationships; the professional identity of scientists; the skill base and available human resources; and perceptions concerning the validity of research methods. It was argued that the difficulties which these factors introduced - particularly in terms of the professional behaviour of scientists - are a result of the historical patterns of institutional development specific to Uganda, as well as the tendency of institutionalized science to perpetuate these problems. The study concluded that, these problems are more serious than problems associated with the introduction of a new method. The problems are systemic in nature and are the result of more fundamental issues relating to the structure of agricultural research. The advocacy of participation has been prescriptive and too coercive. In conclusion, even though, there are no published peer-reviewed materials regarding the willingness of the poultry farmers to pay for participatory research in Nigeria and it is unclear whether the farmers are aware of this approach, research into this area is considered a worthwhile exercise. 


\section{Methodology}

Study Area

The study was carried out in Kwara State, Nigeria. Kwara State is situated entirely within the tropics. It is located between longitude 2'45 and 6 east of Greenwich Meridian and latitude 11'2 and 11'45 North of the equator. It lies to the South of Ekiti, Osun and Oyo. It is bounded in the east by Kogi, North by Niger and west by Benin Republic. Kwara State of Nigeria was created on May 27, 1967. The State population was 2,371,089 (NPC 2006). Agriculture is the main stay of the economy and the principal cash crops grown are: Kola nut, tobacco, sesame seed and palm produce. Agricultural institutes located in the State are the Agricultural and Rural Management Training Institute, (ARMTI), the National Centre for Agricultural Mechanisation and Niger River Basin Authority are all located in Ilorin and the Agricultural Research Project of the Obafemi Awolowo University at Balla provides farmers with vital information on modern agricultural techniques. Also, mineral resources abound in the State. The main ethnic groups are Yoruba, Fulani, Nupe and Baruba. Islam and Christianity are the major religions in the state (Nigeria Galleria 2017).

\section{Type of Data}

The study utilized primary data. The primary data was collected from the sampled farming households using a well-structured and comprehensive questionnaire. The survey was carried out in the year 2014.

\section{Sampling Technique}

The data used in this study were obtained from a household survey of a sample of 102 poultry farmers in the year 2014.For this study, registered poultry farmers lists were used as the sampling frame. The list was obtained through the help of Agricultural Development Program (ADP) Kwara State and Poultry Association of Nigeria (PAN) Kwara State Chapter. The farmers were visited on their meeting days and 102 of the registered farmers were randomly selected. The farmers were visited on their meeting days and randomly selected poultry farmers were interviewed.

\section{Analytical Technique}

The study utilized Descriptive statistics which include frequency and percentages. The study also quantified poultry farmers` willingness-to-pay (WTP) for participatory research using Contingent Valuation (CV) techniques and Probitregression model to examine the factors influencing the poultry farmers' willingness to pay for participatory poultry research. Contingent Valuation method was developed by Ciriacy-Wantrup (1947) is a survey technique that attempts direct elicitation of individuals' (households') preference for a service. It does this 
by asking the respondents in the survey a question or a series of questions about how much they value the good or service. People are asked directly to state or reveal what they are willing to pay in order to gain or avoid some change in provision of a good or service. Alternatively, they may be asked what they are willing to accept, to forego or tolerate a change (Parajuli 2016).

The model was used to assess the resultant effect of the independent variables on the probability of the respondents' willingness to pay for participatory poultry research. A formal probit model allows estimation of probabilities, marginal effects, and a host of ancillary results, but at the cost of imposing the normal or logistic distribution on the data Angrist (2001) the probit model, is a fully parametric specification.

\section{Model Specification}

The models used to achieve the objectives of the study are given below: In determining the average amount that the respondents are willing to pay for participatory poultry research, the model is expressed explicitly as;

Average $\mathrm{WTP}=\sum \mathrm{BD} / \sum \mathrm{N}$

Where,

$\sum$ BDis the sum of the bidding amount. $\sum$ Nis the total number of respondents who were willing to pay.

\section{Probit Model}

To identify the determinants of poultry farmers' willingness to pay for participatory poultry research, the model is expressed explicitly as;

$\mathrm{WTP}=\mathrm{f}\left(\mathrm{X}_{1}, \mathrm{X}_{2}, \mathrm{X}_{3}, \mathrm{X}_{4}, \mathrm{X}_{5}, \mathrm{X}_{6}, \mathrm{X}_{7}, \mathrm{X}_{8} \mathrm{e}_{\mathrm{i}}\right)$

(ii)

Where,

WTP $=$ Willingness of the respondents to pay for participatory poultry research (yes $=1,0$ if otherwise)

$\mathrm{X}_{1}=$ Age of the household head (years)

$\mathrm{X}_{2}=$ Poultry farm size (Average numbers of birds)

$\mathrm{X}_{3}=$ Household size (number of people in each household)

$\mathrm{X}_{4}=$ Education (years)

$\mathrm{X}_{5}=$ Access to extension services (yes $=1,0$ if otherwise)

$\mathrm{X}_{6}=$ Membership of cooperatives (member $=1$, non-member $=0$ )

$\mathrm{X}_{7}=$ Income from poultry production (

$\mathrm{X}_{8}=$ Farming experience (year)

$\mathrm{e}_{\mathrm{i}}$ is the error term and consists of unexpected random variables. 


\section{Results and Discussion}

The socioeconomic characteristics of the farmers were discussed in Table 1.

Table 1. The Socioeconomic Characteristics of the Respondents

\begin{tabular}{|c|c|c|c|}
\hline Socioeconomic variables & Category & Frequency & Percentage \\
\hline \multirow{5}{*}{ Age (years) } & $31-40$ & 29 & 28.43 \\
\hline & $41-50$ & 31 & 30.39 \\
\hline & $51-60$ & 21 & 20.59 \\
\hline & $61-70$ & 18 & 17.65 \\
\hline & $>70$ & 3 & 2.94 \\
\hline \multirow{2}{*}{ Gender } & Male & 72 & 70.59 \\
\hline & Female & 30 & 29.41 \\
\hline \multirow{4}{*}{$\begin{array}{l}\text { Education level of poultry } \\
\text { farmers }\end{array}$} & No education & 1 & 0.98 \\
\hline & Primary & 3 & 2.941 \\
\hline & Secondary & 7 & 6.863 \\
\hline & Tertiary & 91 & 89.22 \\
\hline \multirow{4}{*}{ Marital status } & Single & 9 & 8.824 \\
\hline & Married & 74 & 72.55 \\
\hline & Divorced & 11 & 10.78 \\
\hline & Widowed & 8 & 7.843 \\
\hline \multirow{4}{*}{ Farming experience (years) } & $\leq 5$ & 28 & 27.45 \\
\hline & $6-10$ & 54 & 52.94 \\
\hline & $11-15$ & 12 & 11.76 \\
\hline & $16-20$ & 8 & 7.843 \\
\hline \multirow{2}{*}{$\begin{array}{l}\text { Membership of cooperative } \\
\text { society }\end{array}$} & Member & 51 & 50 \\
\hline & Non-member & 51 & 50 \\
\hline \multirow{2}{*}{ Poultry rearing system } & Battery cage & 78 & 76.47 \\
\hline & Deep litter & 24 & 23.53 \\
\hline \multirow{4}{*}{ Farm size } & $\leq 100$ & 48 & 47 \\
\hline & $101-200$ & 24 & 23.53 \\
\hline & $201-300$ & 18 & 17.65 \\
\hline & $>300$ & 6 & 5.882 \\
\hline \multirow{4}{*}{ Household size } & $1-3$ & 19 & 18.65 \\
\hline & $4-6$ & 74 & 72.55 \\
\hline & $7-9$ & 6 & 5.882 \\
\hline & $>9$ & 3 & 2.941 \\
\hline \multirow{2}{*}{ Access to extension services } & Access & 41 & 40.20 \\
\hline & No access & 61 & 59.80 \\
\hline \multirow{5}{*}{ Poultry farm income ( } & $\leq 100,000$ & 38 & 37.26 \\
\hline & $100,001-200,000$ & 28 & 27.50 \\
\hline & $200,001-300,000$ & 12 & 11.76 \\
\hline & $300,001-400,000$ & 6 & 5.882 \\
\hline & $>400,000$ & 18 & 17.65 \\
\hline
\end{tabular}

Source: Field Survey 2014.

Note: $\$ 1.00=360$ Naira. 
The result in Table 1 shows that about $58.8 \%$ of the respondents were in their middle age and youthful farmers. These groups belong to the economically active population category (Adekunle et al. 2012). While about $38.2 \%$ are fairly old and $2.9 \%$ are really old. This shows that poultry production could be done by any age group irrespective of the age bracket but young people are more involved than the older ones in the study area. The table shows that $70.6 \%$ of the farmers were male, while $29.4 \%$ were female farmers. This indicates that males are relatively more involved in poultry production than female in the study area. Gender is an important factor which can contribute to farmers' willingness to pay for participatory poultry research. This is because the head of the family usually dictates the family decisions. Whether a household is male headed or not could determine a poultry farmers' willingness to pay for participatory research. Most of the respondents were educated $90.04 \%$, this shows that no matter how, education and enlightenment still have a vital role in poultry industry in the study area. Table 1shows that the levels of education attained by the respondents are very high and this may contribute significant role to their willingness to pay for participatory research. The table shows that $72.55 \%$ of the respondents were married. This indicates that poultry production is a good source of income which can cater for the financial need of the family.

Furthermore, Table 1 shows that $72.5 \%$ of the respondents have farming experience which is above 5 years. This means that many of them have been in poultry business for a long time and this will impact on the farmers' willingness to participate in poultry research. Membership of cooperative societies is also an important factor that could influence the willingness of poultry farmers to pay for participatory poultry production research. The table shows that $50 \%$ of the respondents were members of different cooperative societies. From Table 1, 78\% of the respondents employ battery cage system while $24 \%$ were using deep litter system. This may be due to management stress attached to the use of deep litter system and the easiness of using battery cage for big poultry farm. Majority (53\%) of the respondents have their farm sizes above 100 chickens. Farm size and scale of production could affect the willingness of the farmers to pay for participatory poultry research. Household sizes of 4-6 dominate the study area with $72.6 \%$ of respondents. This may be due to the higher number of respondents were married, this also indicate that family labour dominate the labour use among the poultry farmers. Majority of the respondents do not have access to extension services with $59.8 \%$; extension service is usually free of charge, however, due to their limited number not all farmers have access to such services. Access to extension services may create awareness about participatory research services and in turn may positively influence the willingness to pay for participatory poultry research in the study area. About $63 \%$ of the respondents in the study area have their poultry income above $\$ 100,000$ per annum. Income may influence farmers' willingness to pay for participatory poultry research and the farmers with high income, may not really complain of fund if they will required to participate in poultry research. 
Farmers Level of Awareness of Participatory Poultry Research in the Study Area

Table 2. Farmers Level of Awareness

\begin{tabular}{|l|c|c|c|}
\hline \multirow{4}{*}{ Level of awareness } & & Frequency & Percentage \\
\cline { 2 - 4 } & Aware & 40 & 39.22 \\
\cline { 2 - 4 } & Not aware & 62 & 60.78 \\
\cline { 2 - 4 } & Total & 102 & 100 \\
\hline
\end{tabular}

Source: Field Survey 2014.

The Level of awareness of farmers about participatory poultry research is an important concept. Table 2 shows the level of awareness of poultry farmers about poultry farmers' participatory research in Kwara State, Nigeria. The level of awareness of farmers about participatory poultry research is $39.22 \%$ while $60.78 \%$ of the farmers were not aware. The result revealed that the majority $(60.78 \%)$ of the respondents was not aware of participatory poultry research in the study area.

\section{Willingness of Farmers to Pay for Participatory Poultry Research}

Table 3. Willingness to Pay for Participatory Poultry Research

\begin{tabular}{|l|l|c|c|}
\hline \multirow{4}{*}{ Willingness to pay for PPR } & & Frequency & Percentage \\
\cline { 2 - 4 } & Willing & 66 & 64.71 \\
\cline { 2 - 4 } & Not willing & 36 & 35.29 \\
\cline { 2 - 4 } & Total & 102 & \\
\hline
\end{tabular}

Source: Field Survey 2014.

Willingness of farmers to pay for participatory poultry production research is assumed to be one of the key factors which may determine the progress needed to be achieved in the field of poultry participatory research. Table 3 shows that majority $(66 \%)$ of the farmers are willing to pay for participatory poultry research while the percentage of the unwilling farmers is 36\%. Despite that larger percentage of unaware farmers, majority of the farmers are still willing to pay for participatory research. This indicates that people may be willing to participate well and to pay for participatory research, if more awareness carried out among the farmers. This indicates that farmers in the study area will embrace and be ready to pay for participatory poultry research if it is brought to them. This calls for government agencies, the extension agents and researchers to come together and work on the initiation of participatory poultry research. 
Table 4. Average Price Willing to Pay for Poultry Research

\begin{tabular}{|c|c|c|c|c|c|c|}
\hline \multirow{2}{*}{$\begin{array}{l}\text { Amount } \\
\text { (\$)/ } \\
\text { month }\end{array}$} & \multicolumn{5}{|c|}{ Willing respondents } & \multirow{2}{*}{$\begin{array}{c}\begin{array}{c}\text { Unwilling } \\
\text { respondents }\end{array} \\
36\end{array}$} \\
\hline & $\begin{array}{l}\text { Number of } \\
\text { respondent }\end{array}$ & Percentage & $\begin{array}{l}\text { Min } \\
(\#)\end{array}$ & $\begin{array}{c}\operatorname{Max} \\
\text { (\#) }\end{array}$ & $\begin{array}{c}\text { Mean } \\
(\#)\end{array}$ & \\
\hline$\leq 2,000$ & 42 & 41.18 & 2,000 & 2,000 & 2,000 & \\
\hline $\begin{array}{l}2,001- \\
4,000\end{array}$ & 18 & 17.65 & 2,001 & 4,000 & $3,000.5$ & \\
\hline $\begin{array}{l}4,001- \\
6,000\end{array}$ & 4 & 3.921 & 4,001 & 6,000 & $5,000.5$ & \\
\hline$\geq 6,000$ & 2 & 1.961 & 6,000 & 6,000 & 6,000 & \\
\hline
\end{tabular}

Source: Field Survey, 2014.

Table 4 shows the prices which the farmers are willing to offer for participatory poultry research. This is considered as one of the important factor which determines the farmers' readiness to participate in participatory poultry research. It was observed that the average price that farmers are willing to pay is $\$ 2,576$. This average WTP is the amount which the farmers will be willing to pay for participatory poultry research in a month. This amount is recommended and it should not be exceeded if farmers will be encouraged to participate in this type of research in the study area. It could also deduced that the maximum price which a farmer is willing to pay is $\$ 2,910$, while the minimum price is $\$ 2,243$.

Table 5. Probit Regression of Factors Influencing the Farmers Willingness to Pay for Participatory Poultry Research

\begin{tabular}{|l|c|c|c|}
\hline Variables & Coefficient & Standard error & Z-value \\
\hline Household head age (years) & $-0.0423182^{* *}$ & 0.0147375 & -2.87 \\
\hline Farm size & 0.0000572 & 0.0063529 & 0.01 \\
\hline Household size & $0.4024504^{* * *}$ & 0.123371 & 3.26 \\
\hline Education & $0.7166374^{* * *}$ & 0.1984981 & 3.61 \\
\hline Access to extension services & 0.2851119 & 0.3049458 & 0.93 \\
\hline Membership of cooperative & $0.5966463^{*}$ & 0.3184842 & 1.87 \\
\hline Poultry farm income ( $)$ & $8.17 \mathrm{e}-08$ & $2.02 \mathrm{e}-06$ & 0.04 \\
\hline Farming experience & -0.0278451 & 0.0360943 & -0.77 \\
\hline Constant & -1.232387 & 0.8625035 & -1.43 \\
\hline LR chi square $(8)=32.95$ & & & \\
\hline Prob> chi square $=0.0001$ & & & \\
\hline Pseudo R $\mathrm{R}^{2}=0.2512$ & & & \\
\hline Log likelihood $=-49.120944$ & & & \\
\hline
\end{tabular}

Source: Field Survey 2014.

Note: $* * *, * * *$ indicate variable significant at $10 \%, 5 \%, 1 \%$ respectively.

Several factors influence farmers' willingness to participate in poultry research. The probit regression analysis shown in Table 5demonstrated a significant $(\mathrm{p}<0.01, \mathrm{p}<0.05$ or $\mathrm{p}<0.10)$ relationship between socio-economic characteristics and WTP. From the result, the age of the poultry farmers was found to be 
significant at $5 \%$, the household size and level of education were found to be significant at $1 \%$ and membership of cooperative societies was found to be significant at $10 \%$ level statistically. The age of the poultry farmers varies negatively to farmers' willingness to participate in poultry production research. This is logical because there is tendency that the older you are the lesser you become more curious about new things and change, especially the usual practice of your management methods.

The household size of poultry farmers in the study area was found to be positively related to farmers' willingness. This may be because the farmers with large family size have more needs to be met than others and due to this fact; they may be willing to support any practice that will improve their farm income and profit. Also, the educational level varied positively as the farmers' willingness with a t-value of 3.61. This could be because education exposes human mentality to embrace the benefits which may include trying new ways of doing things, and more so more than $89.2 \%$ of the farmers in the study area are educated.

Membership of cooperative societies is also positively related to farmers' willingness with a t-value of 1.87 . This could mean that the inclusion of members in cooperative societies can poised them to be exposed to information, access to extension services and innovations. This may be resulted in their willingness to participate in poultry research because other farmers which have benefited from research before could enlighten other members and this will lead them to follow suit.

\section{Conclusion and Recommendations}

The findings from this study revealed despite that a good number of the farmers were unaware of participatory research, majority of the farmers were still willing to pay for participatory research. This indicates that people may be willing to participate well and to pay for participatory research, if more awareness carried out among the farmers. This indicates that farmers in the study area will embrace and be ready to pay for participatory poultry research if it is brought to them. The results of the study also showed that age of the poultry farmers, the household size, level of education and membership of cooperative societies were significant factors influencing farmers decision to pay for participatory poultry research. The study concluded that both the governments and non-governmental organization should create awareness and develop strategies that will encourage participation and willingness to pay for participatory poultry research. Policy makers and other relevant stakeholders should take advantage of the significant socio-economic factors influencing the decision to participate in poultry research initiatives when formulating policies. This will help improve poultry production, thus helping to bridge the gap in protein shortfall been experienced in the country while the poultry product will be more available. 


\section{References}

Adekunle AO, Adegbite DA, Fakayode SB (2012) Rural financial services and poverty alleviation role of Nigerian agricultural cooperative rural development bank in Oyo State, Nigeria. Nigeria Journal of Agriculture, Food and Environment 8(1): 1-9.

Adeyonu AG, Oyawoye EO, Fabiyi EF, Owolabi AO (2014) Factors influencing consumers' willingness to pay for Nigeria processed chicken in Kwara State, American Journal of Experimental Agriculture 10(5): 1-7.

Aklilu HA (2007) Village poultry in Ethiopia; socio-technical analysis and learning with farmers. PhD Thesis. Wageningen, The Netherlands: Wageningen University.

Angrist J (2001) Estimation of limited dependent variable models with dummy endogenous regressors: simple strategies for empirical practice. Journal of Business and Economic Statistics 29(1): 2-15.

Apantaku SO (2006) Analysis of participation of farmers in participatory poultry production research in Lagos State, Nigeria. Livestock Research for Rural Development 18(7): 1-12.

Bentley JW (2000) Facts, fantasies, and failures of farmer participatory research. E1 Zamorano: University of Arizona.

Birner R, Davis K, Pender J, Nkonya E, Anandajayasekeram P, Ekboir J et al. (2006) "From best practice fit:" a framework for analyzing agricultural advisory services worldwide. Development Strategy and Governance Division, Discussion Paper No. 39. Washington, D.C., USA: International Food Policy Research Institute (IFPRI).

Chambers R, Pacey A, Thrupp LA (1989) Farmer first: farmer innovation and agricultural research. London: Intermediate Technology publications.

Ciriacy-Wantrup SV (1947) Capital returns from soil-conservation practices. American Journal of Agricultural Economics 29(4_Part_II): 1181-1196.

Collier P, Dercon S (2009) African agriculture in 50 years: smallholders in a rapidly changing world? Expert meeting on how to feed the world in 2050. Food and Agriculture Organization of the United Nations Economic and Social Development Department.

Emmanuel D, Enoch O, Owusu V, Jordaan H (2016) Impact of agricultural extension service on adoption of chemical fertilizer: Implications for rice productivity and development in Ghana. Wageningen Journal of Life Sciences 79(Dec): 41-49.

FARM-Africa (2001) Farmer participatory research in Southern Ethiopia: the experiences of the farmers' research project. London: Farm Africa 9-10 Southampton Place.

Food and Agriculture Organization - FAO (2014) The State of Food and Agriculture (SOFA): innovation in family farming. Rome, Italy: FAO.

Freeman HA (2001) Comparison of farmer-participatory research methodologies: case studies in Malawi and Zimbabwe. Working Paper Series no. 10. Nairobi, Kenya: Socioeconomics and Policy Program, International Crops Research Institute for the Semi-Arid Tropics.

Fuglie K, Nin-Pratt A (2013) Agricultural productivity: a changing global harvest. Washington D.C., USA: International Food Policy Research Institute, 15-28.

Global Food Security Index (2015) The role of innovation in meeting food security challenges. Special Report. The Economist, Intelligence Unit Limited.

Global Forum for Rural Advisory Services - GFRAS (1997) Fact sheet on extension service. Position Paper: June 2012.

Gonsalves J, Becker T, Braun A, Camplan D, Chavev H, Fajber E et al. (2005) Participatory research and development for sustainable agriculture and natural resource management: a sourcebook. Volume 1: understanding research and development. Laguna, Phillipines/Ottawa, Canada: International Potato Centre - 
Users' Perspectives with Agricultural Research and Development/International Development Research Centre.

Gueye EF (2000) The role of family poultry in poverty alleviation, food security and the promotion of gender equality in rural Africa. Outlook on Agriculture 29(2): 129-136.

Hall A, Nahdy S (1999) New methods and old institutions: the 'systems context' of farmer participatory research in national agricultural research systems: the case of Uganda. Paper 93. Agricultural Research and Extension Network.

Hayami Y, Godo Y (2004) The three agricultural problems in the disequilibrium of world agriculture, Asian Journal of Agriculture and Development 1(1): 3-14.

Husmann C, Von Braun J, Badiane O, Akinbamijo Y, Fatunbi OA, Virchow D (2015) Tapping potentials of innovation for food security and sustainable agricultural growth an Africa-wide perspective. Working Paper 144. Bonn, Germany: Center for Development Research, University of Bonn.

Ibrahim HY, Dennis GO, Ogezi E (2013) Willingness and capacity to pay for extension services by poultry farmers in Nasarawa State Nigeria. IJASRT in EESs 3(3): 126131.

Kassie M, Jaleta M, Shiferaw B, Mmbando F, De Groote H (2012) Improved maize technologies and welfare outcomes. In Smallholder Systems: Evidence From Application of Parametric and Non-Parametric Approaches. Selected Paper for IAAE Triennial Conference, Foz do Iguaçu, Brazil, 18-24 August, 2012.

Marilee K (2000) Monitoring and evaluating stakeholder participation in agriculture and rural development projects: a literature review. FAO SD-Dimensions. Retrieved from: http://www.fao.org/waicent/faoinfo/sustdev/PPdirect/Ppre0074.htm. [Accessed: 13 September 2020.]

Mbabazi EG (2015) Cost effectiveness of and willingness to pay for vaccination of village free-range poultry against Newcastle disease in Iganga district. MSc Thesis. Uganda: Makerere University.

McCalla AF (2001) Challenges to world agriculture in the $21^{\text {st }}$ century. Agricultural and Resource Economics 4(3): 1-4.

National Bureau of Statistics - NBS (2009) Social statistics in Nigeria. Abuja: NBS.

National Bureau of Statistics - NBS (2014) Social statistics in Nigeria. Abuja: NBS.

National Population Census - NPC (2006) Retrieved from: www.nigerianstat.gov.ng. [Accessed 10 November 2019.]

Ndegwa JM (2013) Improving indigenous chicken production in Kenya - a livelihood strategy. LAP Lambert Academic Publishing.

Ndegwa JM, Shephered DD, Norrish P, Mead R, Kimani CW, Wachira M et al (2013) Participatory strategic approach to development of improved indigenous poultry systems in East Africa. Global Journal of Agricultural Research 1(2): 14-28.

Ndegwa JM, Mead RN, Shepherd DD, Kimani CW, Wachira AM, Siamba DN (2015) Evaluating interventions uptake in indigenous chicken production in a participatory research with smallholder farmers in Kenya. Journal of Agricultural Studies 3(2): $145-165$.

Nigeria Galleria (2017) Kwara State. Retrieved from www.nigeriagalleria.com/Nigeria/ States_Nigeria/K wara. [Accessed 10 November 2019.]

Oakley P (1991) Projects with people: the practice of participation in rural development. Geneva, Switzerland: ILO Publications, International Labour Office.

Oladele IO (2002) Farmers feedback on pig production technology in Kwara State, Nigeria. Livestock for rural development. Retrieved from: http://www.cipav.org.co/Ir rd/Irrd 14/5/olad 145.htm. [Accessed 10 November 2019.] 
Oyeniyi OO, Adesiyan IO, Ayoade RA (2008) Constraints to utilization of poultry production technology among farmers in Oyo State, Nigeria. Journal of Human Ecology 24(4): 305-309.

Parajuli A (2016) Application of contingent valuation method in natural resource in Nepal. Term Paper- SFM 703. Natural Resource Economics. Nepal: Kathmandu Forestry College.

Scoones I, Cousins B (1989) A participatory model of agricultural research and extension: the case of vleis, trees and grazing schemes in the dry south of Zimbabwe. Zambezia XVI(i): 45-65.

Spielman DJ, Birner R (2008) How innovative is your agriculture? Using innovation indicators and benchmarks to strengthen national agricultural innovation system. Agriculture and Rural Development Discussion Paper 41. Washington, D.C., USA: The World Bank. 
